\title{
Dehumanizing trends in combat sports
}

\section{Opinion}

Sports and martial arts educators teach various forms of self-defense that are fully justified by the biological, historical and psychological needs of man. For thousands of years people have had to fight for survival against the forces of nature, animals and other people. They learned different ways (techniques) to fight, they invented the weapons. In this way appeared the martial arts used in wars and in self-defense (accepted by law as "necessary defense"). Of martial arts arose combat sports that allow for the safe and regulated rivalry and learning the various forms of combat. However, we need to remember that fighting skills and physical fitness - axiological neutral - can be used for a variety of purposes, including unworthy and criminal. Therefore, it is the duty of the didactics of sport to teach lawful behavior and to develop (in addition to the skills and abilities) the axiological and ethical competences of the pupils' personalities. Their underdevelopment and lack of integral education lead to the escalation of violence and many other negative phenomena in the borderline of social pathology, which can be described as dehumanizing sport trends or deviations. They appear in various forms:

a. As the development, commercialization and favoring by electronic media of bloody neo-gladiatorial (or neo-pseudo gladiatorial) fights as "sport";

b. As brutal behavior of team players;

c. As promotion of the specific, often absurd language of sports commentators' (they do not distinguish aggression from bravery or dynamics and often say that they need to play, run and even swim "aggressively" to win the competition);

d. As a limitation of the teaching to only martial techniques and physical preparation;

e. As lack of knowledge about the scientific basis of training, sports ethics and the legal basis for the necessary defense and self-defense;

f. As organizing children's fights in cages, etc.

In general, it all means favoring a commercialized "culture" of violence that provides - like gladiatorial and animals fights in ancient Rome - cheap mass entertainment. This "culture" of violence does not, of course, have anything to do with the declared values of Christianity and modern education systems. It also has nothing to do with the educational values of Olympic sport. The authors of the Declaration, entitled "Sport and Fair Play in the 21st Century" - announced by the International Committee for Fair Play in December 2007 at the UNESCO headquarters in Paris - recall that sport must be a vehicle of positive values. Rivalry cannot lead to brutality or endanger the health of athletes. Therefore, the authors of this document are against all forms of violent, aggressive behavior in sport, against doping and aggressive commercialization of sport. They rightly claim that these phenomena are a denial of standards and the pedagogical model of sport.
Volume I Issue 2 - 2017

Jan Harasymowicz

PawełWłodkowic University College, Plock, Poland

Correspondence: Jan Harasymowicz, Paweł Włodkowic University College, Plock, Poland, Email janharasymowicz@wp.pl

Received: June 01, 2017 | Published: June 06, 2017

An international initiative to counteract the culture of violence was launched in 2015 by the electronic journal Archives of Budo, in which the author of this article co-operates as a member of the editorial board. This magazine, together with Jan Dlugosz Academy in Czestochowa, organized the international congress: Health and Martial Arts in Interdisciplinary Approach, under the patronage of Lech Wałesa. The Nobel Peace Prize backed the initiative of Archives of Budo and the Congress's mission, symbolically expressed in the Declaration "HMA against MMA" (Health and Martial Arts against Mixed Martial Arts). The goal of the Congress was the scientific justification for the sustained strengthening of all dimensions of health through the rational practice of sport and martial arts as a counterbalance to the expansion of the culture of violence. The organizers of the Congress were primarily concerned with initiating the solidarity of scientists, Nobel Prize winners, mass media and other subjects with the idea of the "HMA v. MMA" Declaration supported by the authority of Lech Wałęsa, example of nonviolent struggle.

The subject of the Congress, which was also attended by scientists from Japan, covered a wide range of issues: from playthings for training children, the use of martial arts in health training, injury prevention, rehabilitation and therapy for the art of self-defense and the aesthetic and pathological problems of combat sports. Let's not forget that martial arts' training also offers comprehensive benefitshealth, axiological and utilitarian - only when it provides protection for human health and dignity is based on a rational, complete training system and it is led by wise, competent sports didactics. ${ }^{1,2}$

\section{Acknowledgements}

None.

\section{Conflict of interest}

Author declares there is no conflict in interest in publishing the article.

\section{References}

1. Harasymowicz J, Novikov S. Axiological, ethical and utilitarian benefits of UNIFIGHT. Archbudo. 2013;9(4):227-232.

2. Harasymowicz J, Kalina RM. Honourable self-defence-the theoretical and methodological basis of training. Wydawnictwo Novum, Plock. 2006. 